\title{
Use of the Ogawa-Kudoh method to isolate mycobacteria in a tuberculosis reference laboratory in northwestern Paraná, Brazil
}

\author{
Fernanda Schaefer Borges da Silva, Aline Lemes Castilho, Flaviane Granero Maltempe, \\ Rosãngela Zampieri Pina, Elisa Keiko Hirayama Takao, Vera Lúcia Dias Siqueira, \\ Rosilene Fressatti Cardoso, Katiany Rizzieri Caleffi-Ferracioli*
}

\author{
Department of Clinical Analysis and Biomedicine, State University of Maringa, Maringá, PR, Brazil
}

\begin{abstract}
Culturing is the gold standard method for confirming a diagnosis of tuberculosis (TB). The Brazilian Ministry of Health recently proposed the use of the Ogawa-Kudoh method for sputa cultures to detect Mycobacterium tuberculosis. The aim of the present study was to evaluate 8 years of using the OgawaKudoh method in a TB reference laboratory in northwestern Paraná, Brazil. The present study consisted of a retrospective analysis of sputa cultures records for the detection of mycobacteria using the Ogawa-Kudoh method in the Laboratory of Medical Bacteriology, Laboratory of Teaching and Research in Clinical Analysis (LEPAC), State University of Maringá, from July 2003 to September 2011. The following variables were analyzed: Ziehl Neelsen (Z-N) smears and cultures results and the age and gender of the patients. Sputa samples from 3,231 patients with suspected TB were analyzed. Of these, $67.17 \%$ were male with an average age of 45.58 years. Of the total number of $\mathrm{Z}$-N-negative samples $(n=2,949), 42$ $(1.42 \%)$ were positive for M. tuberculosis $(p>0.05)$. The Ogawa-Kudoh method is an excellent tool for diagnosing pulmonary TB. It is easy to perform, requires less biosafety equipment than the Petroff method, has a low cost, and has good sensitivity for detecting of M. tuberculosis.
\end{abstract}

Uniterms: Mycobacterium tuberculosis/detection. Ogawa-Kudoh method/evaluation. Tuberculosis/ diagnosis

A cultura é o método padrão ouro para confirmação da tuberculose (TB). O Ministério da Saúde Brasileiro propôs, recentemente, a utilização do método de Ogawa-Kudoh para cultura de escarro na deteç̧ão de Mycobacterium tuberculosis. O objetivo deste estudo foi avaliar oito anos de utilização do método de Ogawa-Kudoh na rotina de um laboratório de referência na região noroeste do Paraná, Brasil. Realizouse estudo retrospectivo dos registros das culturas de escarro para a deteç̧ão de micobactérias, usando o método Ogawa-Kudoh conduzido no Laboratório de Bacteriologia Médica, Laboratório de ensino e pesquisa em Análises Clínicas (LEPAC) da Universidade Estadual de Maringá (UEM), de Julho de 2003 a Setembro de 2011. As seguintes variáveis foram analisadas: esfregaço Ziehl Neelsen (Z-N), cultura, idade e sexo do paciente. Analisaram-se 3.231 amostras de escarro de pacientes com suspeita de tuberculose. Destes, $67,17 \%$ eram do sexo masculino com idade média de 45,58 anos. Do total de amostras Z-N negativas $(\mathrm{n}=2.949), 42$ amostras $(42 / 2949,1,42 \%)$ apresentaram cultura positiva para M. tuberculosis $(\mathrm{p}>0,05)$. A utilização do método Ogawa-Kudoh representa excelente ferramenta para o diagnóstico precoce da TB pulmonar. É de fácil execução, requer menos equipamentos de biossegurança do que o método de Petroff, apresenta baixo custo e boa sensibilidade para deteç̧ão de M. tuberculosis.

Unitermos: Mycobacterium tuberculosis/detecção. Método de Ogawa-Kudoh/avaliação. Tuberculose/ diagnóstico.

*Correspondence: K. R. Caleffi. Laboratório de Bacteriologia Médica, DAB, Universidade Estadual de Maringá. Av. Colombo, 5.790. Jardim Universitário, 87020-900 - Maringá - PR, Brasil. E-mail: katianyrcf@gmail.com 


\section{INTRODUCTION}

Tuberculosis (TB) is associated with high morbidity and mortality worldwide. It is caused by Mycobacterium tuberculosis, an acid fast bacillus (AFB) that has a generation time of 14-20 $\mathrm{h}$ and can withstand weak disinfectants by having a cell wall composed of long fatty acids, including mycolic acid (Campos, 2006).

The World Health Organization (WHO) estimated that there were 12.0 million cases of TB (range, 11-14 million) in 2010. This is equivalent to 178 cases per 100,000 individuals. A total of $80 \%$ of the new cases annually is concentrated in 22 countries, among which is Brazil. In Brazil, TB predominates in males (2:1 male:female ratio). Although it has a higher incidence in young adults, it is also associated with high rates in the elderly (WHO, 2011).

The diagnosis of TB is based on clinical history, radiological findings, and the tuberculin skin test and confirmed by AFB microscopic detection in Ziehl-Neelsen (Z-N) smears or cultures in appropriate medium. The Z-N assay is the most frequently used for TB diagnosis, but it cannot distinguish among Mycobacterium species. A negative Z-N result cannot rule out TB in patients with a small number of bacilli (Bollela et al., 1999).

The detection of M. tuberculosis DNA using polymerase chain reaction (PCR) is fast and specific and shows high sensitivity that is comparable to culture. It can be performed in one day to provide appropriate early treatment and better control of the disease. However, this methodology is not yet feasible in public healthcare (Bollela et al., 1999).

Cultures are still the gold standard for confirming a diagnosis of TB. It is more sensitive and specific than microscopy and allows clinicians and technicians to perform susceptibility testing (Ferreira et al., 2005). In addition to guiding antibiotic therapy, cultures are fundamentally important for treatment monitoring to avoid the selection of resistant strains that can worsen the clinical status of the patient.

The Brazilian Ministry of Health currently recommends performing cultures in $\mathrm{Z}-\mathrm{N}$-negative patients with suspected pulmonary $\mathrm{TB}$, for diagnosing extrapulmonary TB (i.e., paucibacillary patients), in TBresistant antimycobacterial drug cases, and for diagnosing TB in human immunodeficiency virus-positive patients (Brazil, 2010).

According to Fallow and Kennedy (1979), the sensitivity of the culture can range from $20 \%$ to $90 \%$, depending on the treatment performed in the sample prior to culture. Appropriate sample decontamination is required to promote the elimination of the microbiota and environmental microorganisms, thus allowing the growth of mycobacteria.

The Ogawa-Kudoh method was introduced in our laboratory routine because of the satisfactory results reported by Takao et al. (2005). Recently, the Ministry of Health proposed the use of the Ogawa-Kudoh method to isolate mycobacteria in sputa. The present study evaluated 8 years of using the Ogawa-Kudoh method in a TB reference laboratory in northwestern Paraná, Brazil.

\section{MATERIAL AND METHODS}

A retrospective study was conducted by reviewing the results of Z-N smears and sputa cultures performed using the Ogawa-Kudoh method (Kudoh, Kudoh, 1974; Takao et al., 2005) in the Laboratory of Medical Bacteriology, Laboratory of Teaching and Research in Clinical Analysis (LEPAC), State University of Maringá, Paraná, Brazil.

The study included all patients with suspected pulmonary TB who were referred to the LEPAC from July 2003 to September 2011. The study was approved by the Ethics Committee in Human Research (COPEP; protocol no. 565/2011) at the State University of Maringá.

For data collection, records from the Laboratory of Medical Bacteriology were reviewed with regard to Z-N smears, cultures results, patients gender and age.

The data were tabulated, and the frequencies were calculated and analyzed using the McNemar test (BioStat 5.0 software). Values of $p<0.05$ were considered statistically significant.

\section{RESULTS}

From July 2003 to September 2011, 3,231 sputa samples from suspected TB patients were analyzed. The average age of the patients was 45.58 years $(\mathrm{SD} \pm 17.89$ years). Age information was not found in the records for 168 samples. More than half of the patients samples $(2,170 / 3,231 ; 67.17 \%)$ were from male.

Z-N smears were positive in $8.73 \%(282 / 3,231)$ of the sputa samples, ranging from + to +++ , and $91.27 \%$ $(2,949 / 3,231)$ were negative. Cultures were positive in $9.20 \%(297 / 3,231)$ of the samples $(71.15 \%$ of male patients; age range, 20-39 years). Among the Z-N-negative samples $(n=2,949)$, a total of $1.43 \%(42 / 2,949)$ had positive cultures using the Ogawa-Kudoh method ( $p=0.091$; Fig. 1). M. tuberculosis was identified in $92.86 \%(39 / 42)$ and nontuberculosis mycobacteria were identified in $7.14 \%(3 / 42)$ of the cultures. 


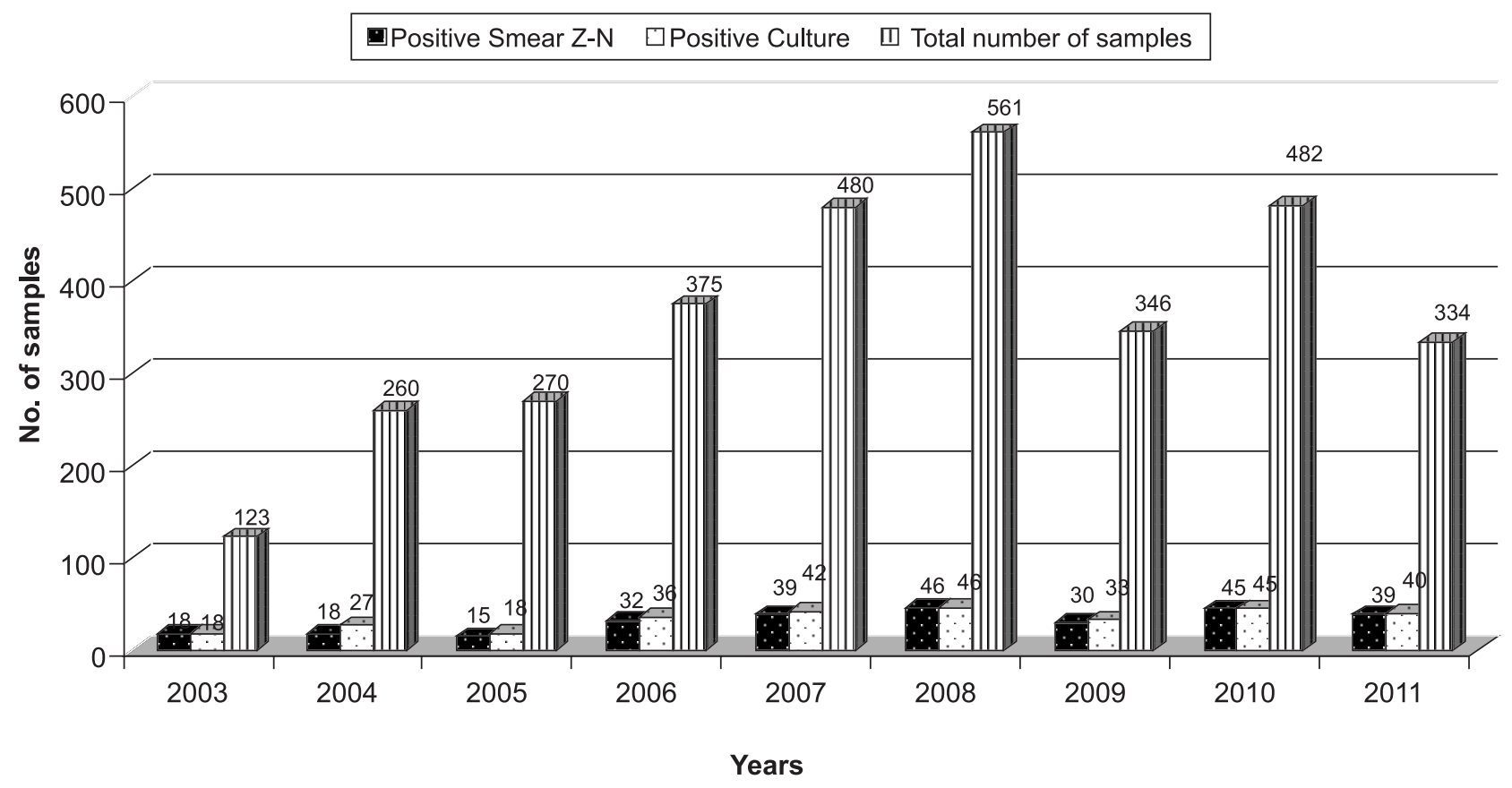

FIGURE 1 - Positive Z-N smears and cultures of sputa samples from suspected TB patients processed from 2003 to 2011 in the Laboratory of Medical Bacteriology, Laboratory of Teaching and Research in Clinical Analysis, State University of Maringá, Paraná, Brazil.

\section{DISCUSSION}

A total of 3,231 samples from patients with suspected TB attended at LEPAC from 2003 to 2011, 67.1\% $(2,170 / 3,231)$ were from male with an average age of 45.58 years $(\mathrm{SD} \pm 17.89$ years). A predominance of males was also observed in other studies (e.g., Ferreira et al., 2005). Although the present results were consistent with other studies, no clear explanations for such difference, between male and female, have been provided. Some authors believe that the predominance of males may be related to underreporting in women, lifestyle, and a higher level of healthcare in women (Vendramini et al., 2005).

Ferreira et al. (2005) showed that although Z-N smears are fast and inexpensive for TB diagnosis, this method has limitations. A positive result is only achieved when at least $5,000 \mathrm{bacilli} / \mathrm{cm}^{3}$ are identified in the sputum. Thus, mycobacterial cultures, although more time-consuming, are the gold standard for diagnosing TB. Culture has higher sensitivity, allowing the determination of mycobacterial species and drug susceptibility testing accomplishment (Conde et al., 2009; Boffo et al., 2003). In the present study, $1.42 \%(42 / 2,949)$ of the Z-N-negative samples were culture positive for mycobacteria. Although this result was not statistically significant $(p>0.05)$, it was extremely beneficial for 42 patients because this allowed the early diagnosis of pulmonary TB and starting the treatment to interrupt the bacilli transmission. Most positive cultures were found in males of working age, which is consistent with the prevalence found in the population studied (Teixeira, Costa, 2011).

The Ogawa-Kudoh method has been shown to effectively detect $M$. tuberculosis and nontuberculosis mycobacteria (Takao et al., 2005). These authors found no differences in the sensitivity and contamination of sputa cultures between the Ogawa-Kudoh and Petroff methods. Another advantage of the Ogawa-Kudoh method was a reduction of the time of onset of visible colonies in culture. In addition to being inexpensive, fast, and easy to perform, the Ogawa-Kudoh method is advantageous for microbiologists because of the low risk of contamination once the sample is inoculated using swabs, and no centrifugation process is necessary.

The Ogawa-Kudoh method is a good option for isolating AFB in laboratories with limited financial resources, particularly in developing countries, where the rates of multidrug-resistant $\mathrm{TB}$ and extremely resistant $\mathrm{TB}$ are increasing. Such laboratories sometimes do not have all of the recommended biosafety equipment to perform the Petroff method, especially centrifuges with protection against the production of aerosols. The Ogawa-Kudoh method is faster than the Petroff method and requires fewer employees. Once the sputa samples are cultured, small laboratories can send the cultures to a reference laboratory 
that has the appropriate apparatus to identify and perform drug susceptibility tests for mycobacteria.

\section{CONCLUSION}

In countries with a high prevalence of $\mathrm{TB}$, such as Brazil, the early diagnosis of TB is of paramount importance to start effective treatment of disease and decrease the transmission of the bacilli. Based on our experience over the past 8 years, the Ogawa-Kudoh method is a good laboratory tool for diagnosing TB, including in paucibacillary patients. The Ogawa-Kudoh method can improve TB diagnosis in laboratories with limited financial resources or with a high TB workload.

\section{REFERENCES}

BOFFO, M.M.S.; MATTOS, I.G.; RIBEIRO, M.O.; JARDIM, S.; SOUZA, V.C. Diagnóstico laboratorial da tuberculose na cidade do Rio Grande, RS, Brasil. Rev. Bras. Anal. Clin., v.35, n.1, p.35-38, 2003.

BOLLELA, V.R.; SATO, D.N.; FONSECA, B.A. Problemas na padronização da reação em cadeia da polimerase para diagnóstico da tuberculose pulmonar. Rev. Saúde Pública, v.33, n.3, p.281-286, 1999.

BRASIL. Ministério da Saúde. Secretaria de Vigilância em Saúde. Programa Nacional de Controle da Tuberculose. Manual de recomendações para o Controle da Tuberculose no Brasil. Brasília: Ministério da Saúde, 2010. p.24-25.

CAMPOS, H.S. Etiopatogenia da tuberculose e formas clínicas. Pulmão RJ, v.15, n.1, p.29-35, 2006.

CONDE, M.B.; DE MELO, F.A.F.; MARQUES, A.M.C.; CARDOSO, N.C.; PINHEIRO, V.G.F.; DALCIN, P.T.R. et al. III Diretrizes para tuberculose da Sociedade Brasileira de Pneumologia e Tisiologia. J. Bras. Pneumol., v.35, n.10, p.1018-1048, 2009.
FERREIRA, A.A.A.; QUEIROZ, K.C.S.; TORRES, K.P.; FERREIRA, M.A.F.; ACCIOLY, H.; ALVES, M.S.C.F. Os fatores associados à tuberculose pulmonar e a baciloscopia: uma contribuição ao diagnóstico nos serviços de saúde pública. Rev. Bras. Epidemiol., v.8, n.2, p.142-149, 2005.

KUDOH, S.; KUDOH, T. A simple technique for culturing tubercle bacilli. Bull. Wld. Hlth. Org., v.51, n.1, p.71-82, 1974.

TEIXEIRA, E.C.; COSTA, J.S. O impacto das condições de vida e da educação sobre a incidência de tuberculose no Brasil. Rev. Econ., v.37, n.2, p.106-123, 2011.

TAKAO, E.K.H.; NOCCHI, S.R.; SIQUEIRA, V.L.D.; CARDOSO, M.A.; PERON, M.L.D.; CALEFFI, K.R.; CARDOSO, R.F.C. Comparação de métodos de cultivo para o diagnóstico laboratorial da tuberculose pulmonar. Acta Sci. Health Sci., v.27, n.2, p.183-188, 2005.

VENDRAMINI, S.H.F.; GAZETTA, C.E.; NETTO, F.C.; CURY, M.R.; MEIRELLES, E.B.; KUYMJIAN, F.G.; VILLA, T.C.S. Tuberculose em município de porte médio do Sudeste do Brasil: indicadores de morbidade e mortalidade, de 1985 a 2003. J. Bras. Pneumol., v.31, n.3, p.237-243, 2005.

WORLD HEALTH ORGANIZATION. WHO Report 2011

- Global Tuberculosis Control. Available at: <http://goo. g1/9E7zu>. Accessed on: 20 Aug. 2012.

Received for publication on $15^{\text {th }}$ September 2012 Accepted for publication on $08^{\text {th }}$ May 2013 